\title{
Effects on milk yield and composition of infusions of different levels and natures of energy into the digestive tract of dairy cows
}

\author{
C Hurtaud, H Rulquin, R Vérité
}

INRA, Station de Recherches sur la Vache Laitière, Saint-Gilles, 35590 L'Hermitage, France

The positive effect of concentrates on milk production and especially on protein content (Remond, 1985) has been classically imputed to an increased production of propionic acid. However, propionic infusion did not always lead to an increase in protein content (Hurtaud et al, 1992). Other factors such as an increase in energy level or in intestinal glucose supply might explain this effect.

A rumen infusion of propionic acid (13.41 $\mathrm{mol} / \mathrm{d})$ was compared with water as a negative control ( $90 \%$ of energy needs) and 2 positive isoenergetic controls $(100 \%$ of energy needs) consisting of intra-ruminal infusion of $17 \mathrm{~mol} / \mathrm{d}$ of a normal VFA mixture (64\% acetic, $21 \%$ propionic and $15 \%$ butyric acids) or intra-duodenal infusion of glucose (1295 g/d).

Four ruminally and duodenally-fistulated Holstein cows were used 2 months post partum in a $4 \times 4$ Latin square ( 2 weeks/period). The diet consisted of $60 \%$ maize silage, $10 \%$ hay, $17.5 \%$ energy concentrate and $12.5 \%$ soya bean meal and covered $90 \%$ of energy requirements.
Increasing energy input without change in VFA profile improved milk yield $(+0.9 \mathrm{~kg} ; P<0.05)$, but did not change protein and fat content whereas lactose content tended to increase. At a similar energy input, a shift from acetic to propionic acid profile did not change milk yield or protein or casein content but caused a large decrease in milk fat content $(-4.6 \mathrm{~g} / \mathrm{kg} ; p<0.05)$. Compared to propionic treatment, glucose led to the same fat content, decreased milk yield but improved protein and casein content $(+0.8 \mathrm{~kg} ; P<0.05)$.

In contrast to protein concentration, protein yield was more sensitive to energy level than to nature of energy infused since the large positive effect of glucose on concentration was associated with a decrease in milk yield and therefore protein yield was unaffected.

Hurtaud C, Rulquin H, Vérité R (1992) Ann Zootech 41, 90

Remond B (1985) Bull Tech CRZV 62, 53-67

Table I. Effect of level and nature of energy on milk yield and composition.

\begin{tabular}{lccccc}
\hline \multirow{2}{*}{ Energy } & Low & \multicolumn{4}{c}{ High } \\
\cline { 3 - 6 } & & $\begin{array}{c}\text { VFA } \\
\text { mixture }\end{array}$ & $\begin{array}{c}\text { Propionic } \\
\text { acid }\end{array}$ & Glucose & SE \\
\hline Energy (UFL/d) & $15.1 \mathrm{~A}$ & $17.2 \mathrm{~B}$ & $17.1 \mathrm{~B}$ & $17.3 \mathrm{~B}$ & 0.2 \\
Milk yield (kg/d) & $26.7 \mathrm{~A}$ & $27.6 \mathrm{~B}$ & $28.1 \mathrm{~B}$ & $26.3 \mathrm{~A}$ & 0.4 \\
Milk lat content $(\mathrm{g} / \mathrm{kg})$ & $35.8 \mathrm{~A}$ & $36.1 \mathrm{~A}$ & $31.5 \mathrm{~B}$ & $31.8 \mathrm{~B}$ & 1.0 \\
Milk protein content $(\mathrm{g} / \mathrm{kg})$ & $28.9 \mathrm{~A}$ & $29.2 \mathrm{~A}$ & $29.6 \mathrm{AB}$ & $30.7 \mathrm{~B}$ & 0.7 \\
Milk casein content $(\mathrm{g} / \mathrm{kg})$ & $23.5 \mathrm{~A}$ & $23.9 \mathrm{~A}$ & $24.1 \mathrm{~A}$ & $24.9 \mathrm{~B}$ & 0.7 \\
Milk lactose content $(\mathrm{g} / \mathrm{kg})$ & 45.5 & 47.3 & 48.1 & 45.1 & 3.6 \\
\hline
\end{tabular}

A, B : $P<0.05$ 